DOI:

Валентина Тимошенко, аспірантка кафедри освіти дорослих Національного педагогічного університету імені М.П. Драгоманова

\title{
ОБГРУНТУВАННЯ МОДЕЛІ ФОРМУВАННЯ КОМУНІКАТИВНОЇ КОМПЕТЕНТНОСТІ ЗВ' ЯЗКУ В МАЙБУТНІХ МЕНЕДЖЕРІВ У ЗАКЛАДАХ ВИЩОЇ ОСВІТИ
}

У статті здійснено теоретичне й методичне обтрунтування розроблення моделі формування комунікативної компетентності зв'язку в майбутніх менеджерів у закладах вищої освіти; удосконалено понятійно-категоріальний апарат дослідження комунікативної компетентності зв'язку в майбутніх менеджерів - “інформаційної безпеки у сфері освіти, науки й інноватики”, “інформачійне суспільство наукових знань”, “комунікативна компетентність"; обтрунтовано критерії, рівні формування комунікативноі компетентності зв'язку в майбутніх менеджерів у запропонованих організаційно-педагогічних умовах закладів вищої освіти.

Ключові слова: комунікативна компетентність; майбутні менеджери; заклад вищої освіти; модель; критерії; рівні; умови.

Jim. 8.

Valentyna Tymoshenko, Postgraduate Student of the Adult Education Department, National Mykhaylo Drahomanov Pedagogical University

\section{SUBSTANTIATION OF THE MODEL OF FORMATION OF COMMUNICATIVE COMPETENCE OF COMMUNICATION IN FUTURE MANAGERS IN HIGHER EDUCATION INSTITUTIONS}

The article provides a theoretical and methodological justification for the development of a model fo of formation of communicative competence of communication in future managers in higher education institutions; improved the conceptual and categorical apparatus of research of communicative competence of communication in future managers - "information security in the field of education, science and innovation", "information society of scientific knowledge", "communicative competence". The criteria for establishing the formation of communicative competence of communication in future managers in the free economic zone according to the levels of metrics defined in the relevant subsystem are developed and substantiated. In the structural-logical chain of presentation by levels in the criteria, the correspondence is determined: sufficient public access to equality of students in the socio-global dimension of academic mobility of the first criterion (vocabulary of communicative interaction, professional-categorical apparatus for solving ICT problems in the field ability of anti-crisis quality management of educational policy); second (rational-optimal formation of communicative competence of communication for ICT activity according to technical regulations of normative-legal regulation); third (semantics of the organization of the process of professional training for systemic ICT activities with software for education, science and innovation with practical capabilities of communicative forecasting and modeling of the state of development of socio-cultural forms); high noosphere-qualitative creative realization of prolonged employment and development of managers of the first criterion (formation of communicative competences of development of systems of nonlinear character of the organization of professional training in ZVO); second (formation of competencies in the ability of administrative management to solve problem-specific tasks of personal choice of forms of self-education, management, organization and improvement according to innovative methods of consulting services of IR communication of legal and technical regulation of management); third (relevance of the formation of communicative competence of future managers in vocational training, expressed in socio-economic, environmentally safe capabilities of sustainable administrative influence on socio-cultural forms of free economic education with the realization of academic potential).

Keywords: communicative competence; future managers; higher education institution; a model; criteria; levels; conditions.

П остановка проблеми. Науковий аналіз проблеми професійної підготовки майбутніх менеджерів у закладах вищої освіти (далі - ЗВО) дає підстави для актуалізації питання формування у здобувачів освіти комунікативної компетентності зв'язку та розв'язання суперечностей між : станом якості організації освітнього процесу формування комунікативних компетентностей зв'язку та необхідністю модернізації навчальнометодичного та інформаційно-технологічного забезпечення професійної підготовки менеджерів у закладах вищої освіти; глобальними та соціальними вимірами академічної мобільності та 


\section{ОБГРУНТУВАННЯ МОДЕЛІ ФОРМУВАННЯ КОМУНІКАТИВНОЇ КОМПЕТЕНТНОСТІ ЗВ'ЯЗКУ В МАЙБУТНІХ МЕНЕДЖЕРІВ У ЗАКЛАДАХ ВИЩОЇ ОСВІТИ}

обмеження життєвого простору безпеки якості здобуття освіти майбутніми менеджерами 3 комунікативними компетентностями в умовах цивільних обмежень пандемії; аксіологоакмеологічними потребами майбутніх менеджерів до комунікативної взаємодії на рівнях, у типах та за призначенням семантики професійної підготовки та відсутністю нормативно-правових гарантій інформаційної безпеки особистості громадянина України. Наукові розвідки виконано у межах держбюджетної теми “Теорія і технологія навчання у системі професійної освіти” (державний реєстраційний номер 0115U000552, 2015-2017 pp.) та плану науково-дослідної роботи “Теоретичні та методичні основи формування системи післядипломної освіти на засадах сталого розвитку" (державний реєстраційний номер 0117U004914, 2016-2019 pp.).

Аналіз основних досліджень і публікацій. Теоретичне і методичне підгрунтя дослідження формування комунікативної компетентності зв'язку в майбутніх менеджерів у ЗВО вивчали науковці Н. Алюшин, О. Антонов, М. Армстронг, П. Бокселл, Т. Василевська, Д. Геберт, Н. Демедишина, С. Загороднюк, Л. Знікіна, В. Князєв, А. Ліпенцев, О. Оболенський, О. Овчарук, Л. Пашко, А. Рачинський, М. Рудакевич, І. Слісаренко, С. Сьомін, В. Токовенко, В. Черевко (комунікативна компетентність майбутніх менеджерів, в тому числі адміністративно-організаиійних, інформаційно-комунікаційних та управлінських) $[1 ; 2 ; 4]$; Б. Ананьєв, І. Булах (психологія ділового спілкування). Актуальними є дослідження психолого-педагогічних та філософськогофундаментальних джерел у ході контентаналізу (Б. Берельсон, П. Мэйрінг, К. Нойендорф, А. Кумар, П. Дж. Стоун, К. Кріппендорф, М. Уайт, Е. Марш, С. Стемлер, Х. Іоффе, Л. Ярдлі) та івент-аналізу інформаційного базису даних ретроспективи розвитку освітньополітичних явищ (І. Артьомов, В. Бакуменко, К. Боришполец, С. Вировий, С. Лейсі, I. Рейтерович, Д. Ріфф, С. Сьомін, С. Телешун, О. Титаренко, Б. Уотсон, Ф. Фіко) [5]; планування освітнього процесу (Ф. Анрі); дослідження суб 'єкт-об 'єктних та суб'єкт-суб 'єктних взаємин (Л. Бакстер), в тому числі теоретикометодичного забезпечення професійних комунікацій зв'язку у системах $3 B O$ динамічною структурою (Я. Корнага, О. Кузьмінська, I. Харченко) [6]; способів кодування аналізованих текстів (К. Карлі) та візуалізованих образів (П. Белл) у соціальній взаємодї учасників системних процесів (Б. Прасад); методології організації хмаро орієнтованого освітньо- наукового середовища (О. Глазунова, Т. Волошина, М. Шишкіна) [3; 8].

Мета статті полягає в теоретичному i методичному обгрунтуванні, розробці моделі формування комунікативної компетентності зв'язку в майбутніх менеджерів у закладах вищої освіти. Завдання дослідження: проаналізувати теоретичні і методичні засади методами контентта івент-аналізу питання інформаційної безпеки у сфері освіти, науки й інноватики та удосконалення понятійно-категоріального апарату дослідження комунікативної компетентності зв'язку в майбутніх менеджерів; обгрунтувати та розробити модель формування комунікативної компетентності зв'язку в майбутніх менеджерів y 3 BO.

Виклад основного матеріалу. Систематизовано тезаурус питання інформаційної безпеки у сфері освіти, науки й інноватики, яку тлумачимо як цілісну систему процесно-апаратного, програмного, інформаційно-технологічного забезпечення організаційних нормативно-правових та технікорегулятивних засобів, орієнтованих на забезпечення захисту: інформаційного простору держави, спільнот, суспільної діяльності та окремих громадян 3 гарантуванням власної гідності та національної самоідентичності від несанкціонованого порушення рубежів витривалості цілісної єдності інформаційноаналітичної системи самобутності з небажаним впливом дисгармонізації гомеостазу; комплекс транскордонних, регіональних і національних інформаційно-комунікаційних ресурсів зв'язку, семантичне призначення інформаційнотелекомунікаційних систем професійної підготовки та поінформування та просвітництва розлогої амплітуди категорій громадськості, яким гарантовано право доступу до будь-якої інформації, особливо навчально-науковопізнавальної в галузях наук та знань менеджеризму системної суспільної діяльності на засадах сталості (циклічного та ациклічного типів історичного генезису); невід'ємну складову державного суверенітету й національної безпеки, що характеризує стан державної захищеності національних інтересів в інформаційній сфері налагодження комунікативної гармонізації зовнішньо-внутрішньої взаємодії зв'язків 3 передбаченням, усуненням та запобіганням загроз системного характеру. Об'єктами інформаційно-комунікаційної безпеки соціокультурних форм організації адмінуправління професійної підготовки $є$ управлінська свідомість та відповідальність, психо-компенсаторна здатність менеджерів з адекватно-врівноваженою психікою, 


\section{ОБГРУНТУВАННЯ МОДЕЛІ ФОРМУВАННЯ КОМУНІКАТИВНОӤ КОМПЕТЕНТНОСТІ ЗВ'ЯЗКУ В МАЙБУТНІХ МЕНЕДЖЕРІВ У ЗАКЛАДАХ ВИЩОЇ ОСВІТИ}

інформаційно-комунікаційні системи зв'язку, що складають інформаційну архітектоніку сфери освіти, науки й інноватики та суспільної системної діяльності на засадах сталості, розвитку державних інтересів; відповідно суб'єктами є : системи державного регулювання семантичного призначення інформаційно-комунікаційного зв'язку за типами, рівнями, орієнтацією, що реалізують свої функції через відповідні органи державної влади шляхом створення системи забезпечення інформаційно-комунікаційної безпеки громадян, суспільних або інституційних форм організації й об'єднань, які наділені повноваженнями іiі забезпечення згідно нормативно-правового та технічного регулювання транскордонної імплементації та чинного законодавства.

Сформульовано генезу з авторської точки зору “інформаційне суспільство наукових знань”глобально-цивілізаційний процес концептуальностратегічного формування і планетарного абрису застосування інформаційно-методичних ресурсів. Інформаційно-аналітичною базою суспільного розвитку на засадах сталості постає інформаційнотехнологічний комплекс забезпечення розвитку сфери освіти, науки й інноватики та комп'ютеризації системної суспільної діяльності, електронної комунікативної взаємодії та IКТ з реалізованих для забезпечення якості, безпеки життя. Перспективи інформатизації розкриті на Всесвітньому саміті 3 оприлюдненням “Декларації принципів” (170 країн світу) з питань інформаційного суспільства (Швейцарія, 2003 р.; Туніс, 2005 р.), де глобальним завданням нового тисячоліття проголошено розбудову орієнтованого на інтереси людей відкритого для всіх і спрямованого на розвиток інформаційного суспільства наукових знань.

Завдяки методологічному обгрунтуванню наукового тезаурусу конкретизовано визначення “комунікативна компетентність ” зі застосуванням засобів вербально-невербального характеру задля досягнення стратегічної мети комунікативної взаємодії у професійно-проблемних ситуаціях, що виокремлюється як критерії комунікативної готовності майбутнього менеджера 3 інформаційно-комунікаційними здатностями налагодження зв'язку професійної комунікативної взаємодії; інтегрованим результатом сформованості $€$ динамічний комплекс комунікативних якостей, здібностей, здатностей, знань, умінь, навичок, готовності, сформованості, спроможності та відповідальності, які необхідні та оптимально достатні для забезпечення комунікативного зв'язку у виконанні функціонально-цільових професійних завдань майбутнього менеджера (комунікативними виявами яких є мультимодусна компонентність зв'язку, семантична динаміка, доступність та відкритість універсалізації засобів інформаційно-технологічного забезпечення). Комунікативна компетентність складається 3 видів мовних, мовленнєвих, культурно-етичних, академічно-комунікативних, що віддзеркалюють пануючі парадигми превалювання галузей науки і знань, комунікативні уміння і навички у контекст професійної взаємодії функціонального призначення, системно-комунікативні дії зв'язку як алгоритмізовано-послідовні етапи реалізації комунікативних умінь і навичок реалізації системно-професійної управлінської діяльності.

Розроблено та обгрунтовано модель формування комунікативної компетентності зв'язку в майбутніх менеджерів у ЗВО згідно запитів соціально-економічного замовлення на професійну підготовку менеджерів 3 комунікативними компетентностями зв'язку для гармонізації сфери освіти, науки й інноватики та суспільної діяльності для сталого розвитку (213 професіонали в галузі обчислень (комп'ютеризації) та обчислювальних систем 2131 - 2131.1 наукові співробітники обчислення, 2131.2 розробники обчислювальних систем; 2139 професіонали комп’ютеризації - 2139.1 наукові співробітники інших обчислень, 2139.2 професіонали інших галузей; 2144 професіонали в галузі електроніки та телекомунікацій - 2144.1 наукові співробітники заявленої сфери, 2144.2 інженери телекомунікацій; 3436 помічники керівників 3436.1 підприємства, установи, організації (референти); 3132 оператори радіо- та телекомунікаційного устаткування та 3139 інші оптично-електронного устаткування, 3435 організатори діловодства -3435.2 за видами економічної діяльності; 3436 помічники керівників - 3436.1 підприємств, установ та організацій, в тому числі 3436.2 виробничих та основних підрозділів, 3436.3 малих підприємств без апарату управління; 41 службовці, пов'язані з інформацією - 411 секретарі та службовці, що виконують операціїза допомогою клавіатури (4111 стенографісти та друкарки, 4112 оператори - машин для оброблення текстів, 4113 із збору даних, 4114 лічильних машин, 4115 секретарі); 412 службовці, зайняті з цифровими даними; 419 інші службовці, пов'язані з інформацією; 422 агенти 3 інформування клієнтів (4222 службовці 3 довідкового інформування, 4223 телефоністи, телеграфісти зв'язку, 4229 укрупнені професії службовців з інформування клієнтів) [7] з метою формування комунікативної компетентності зв’язку в менеджерів у процесі професійної 


\section{ОБГРУНТУВАННЯ МОДЕЛІ ФОРМУВАННЯ КОМУНІКАТИВНОЇ КОМПЕТЕНТНОСТІ ЗВ'ЯЗКУ В МАЙБУТНІХ МЕНЕДЖЕРІВ У ЗАКЛАДАХ ВИЩОЇ ОСВІТИ}

підготовки в ЗВО у функціонально-цільовій niдсистемі зреалізованих засад методологічних (системного, структурно-функціонального, програмно-цільового та інформаційноінноваційного) та навчально-пізнавальних (транспарентний, партисипативний, диверсифікаційний (реноваційний), бінгвінальний, управління якістю) підходів та принцииів - наукового пізнання системної методології, організації освітнього процесу, навчально-пізнавальної діяльності, системного аналізу якості; семантики професійної підготовки : адмінуправління процесом професійної підготовки, навчальнонауково-пізнавальної діяльності, комунікативного зв' язку.

Обгрунтовано змістовно-методологічну підсистему з розробленими освітньо-змістовими модулями дисциплін технологічного забезпечення для менеджерів інформаційно-комунікаційного зв'язку (інформаційно-аналітичний моніторинг освітнього процесу, інформаційно-технологічне забезпечення, ІКТ в освіті та суспільній діяльності); менеджменту та освітньої політики (освітній менеджмент та політика, комунікативний менеджмент, кадровий менеджмент, менеджмент сфери інфокомунікацій, комп'ютерна інженерія та програмного забезпечення, телекомунікація та радіотехніка, інформаційно-технологічний маркетинг та підприємництво); методології наукового дослідження та навчання професійноорієнтованих, фахових та спеціальних дисииплін (галузі знань 073 Менеджмент методології педагогічного, соціального психологокомунікативного, публічного управління, інформаційно-цифрового, системного аналізу якості складових компонентів методики дослідження), статистика, економіка підприємства, методики навчання телекомунікаційної інженерії, інформаційно-комунікаційної техніки зв'язку та електрозв'язку, поштового зв'язку, технології обчислення та програмування, інформаційноаналітичного моніторингу, освітнього моніторингу та метрики політики якості, логістика комунікативного зв'язку, Інтернет-маркетинг, етика ділових комунікацій менеджменту, риторика (спічрайтинг, дипломатичний менеджмент).

Конкретизовано згідно методу Форда (конвеєрної технологічності) організаційнотехнологічну підсистему у складових компонентах системно-процесної реалізації освітніх технологій, ІКТ-управління - (об'єктами адмінуправління соціокультурної організації та видами оргструктур), частково-управлінських процедур реалізації академічного потенціалу 3ВО, алгоритми технологічної організації освітнього процесу - інформаційно-аналітичний та адміністративно-організаційний, релевантний (моніторингу якості освітньої політики та якості безпеки життя) інституційні регламенти ЗВО.

Інформаційно-технологічна та методичноорганізаційна тріада організаційно-технологічної підсистеми синергетичної взаємодії засобів (навчально-пізнавальної, ІКТ, апаратних та програмних складових зв'язку, технічного регулювання), методів навчально-науковопізнавальної діяльності (навчально-пізнавальні, науково-метричні, науково-дослідні, прогностичні, конструкторсько-проектувальні, освітньо-виховні, лабораторно-аналітичного випробування, ідентифікаційно-закріплювальні, діагностикокоригувальні), форм організації адмінуправління професійної цільової підготовки (маніфестнодекларативна, трансляційно-лінійна, калейдоскопічна, мобільна), за організацією навчально-науковопізнавальної діяльності, місцем дислокації та дидактичною метою. На етапах педагогічного дослідження (спонукально-мотиваційний комунікативної взаємодії, аудиту, констатувальний, формувально-конативний і релевантний).

Висновки і перспективи подальших досліджень. Теоретичні та методичні засади професійної підготовки майбутніх менеджерів сформульовано у розумінні: спеціальної професійно-орієнтованої фахової підготовки 3 інформаційно-телекомунікаційним забезпеченням комунікативної взаємодії (суб'єкт-об'єктної, суб'єкт-суб'єктної) за функціонально-цільовим призначенням у комунікативних типах суспільних взаємин та на рівнях організації комунікації передачі інформаційно-аналітичних даних інформаційного вокабуляру на засадах сталої гармонізації сфери освіти, науки й інноватики; базується на підходах - методологічних (системний, структурно-функціональний, програмно-цільовий, інформаційно-інноваційний) $\mathrm{i}$ навчально-пізнавальних (транспарентний, партисипативний, диверсифікаційний (реноваційний), бінгвінальний, управління якістю), принципах наукового пізнання системної методології (фундаментально-філософські, загально- та конкретно-наукові, науки), організації освітнього процесу (наступності, наскрізності, послідовності, неперервності, систематичності, прогностичності та інноваційності), навчально-пізнавальної діяльності (історичної ретроспективи галузей науки і знань, потенціалу рівня пізнання, за сферами системної методології, світоглядності, епохою методології науки), системного аналізу (системної ієрархії, елементаризму, загальної взаємодії розвитку, цілісності, системності, 
формалізму, нормативності, цілепокладання) менеджер інформаційно-комунікаційного зв'язку нової формації- професійно мобільний фахівець, який прогресивно й інноваційно мислить, налаштований на діяльність у команді 3 персональною відповідальністю, умотивований на позитивний результат виконання професійно орієнтованих комунікативних завдань гармонізації суспільної діяльності у сфері освіти, науки й інноватики; професійна підготовка майбутніх менеджерів персоніфікується організаційнопедагогічними умовами (сприятливе IКТсередовище студентоцентрованого навчання портативних освітніх програм наукових та соціальних сервісів, система управління якістю в ЗВО (засади освітньої політики) засобами технічного регулювання загального та спеціального впливу комунікативної взаємодії в умовах гармонізації сфери освіти, науки й інноватики); актуалізація студентоцентрованого ІКТ-середовища зі сприйнятними засобами технологічного забезпечення уможливлює акомодацію мультимодусності, полісемантики, наступності, послідовності, контексності, зв'язку теорії з практикою наукового пізнання між надавачем і здобувачем освітньо-наукових портативно-студентоцентрованих послуг мережевого, змішаного, мобільного та дистанційного навчання дивізіональної, трансляційної, калейдоскопічної, маніфестної форм організації освітнього процесу.

Розроблено та обгрунтовано критерії встановлення сформованості комунікативної компетентності зв'язку в майбутніх менеджерів у ЗВО за рівнями метрики визначено у релевантній підсистемі. Відповідно за критеріями (комунікаційно-мотиваційний, партисипативноконативний, інформаційно-ноосферний) середній мінімально оптимального рівня взаємодії суб'єктсуб'єктної та суб'єкт-об'єктної взаємодії комунікаційно-мотиваційного критерію (аксіологоакмеологічна зацікавленість у фаховій реалізації достойно рівноправного контингенту цільових категорій здобувачів освіти у реалізації можливостей професійної зайнятості, комунікативний вияв взаємодії ІК зв'язку між учасниками процесу профпідготовки); партисипативно-конативного (сприйнятноконативна здатність партисипативного усвідомлення профпідготовки менеджерів 3 виявом комунікативних компетентностей для вирішення ІКТ-завдань гармонізації процесу професійної реалізації); інформаційноноосферного (комунікативні здатності до алгоритмізованої ноосферно-спроможної діяльності гармонізації сфери освіти, науки й інноватики 3 пролонгованою зайнятістю вияву інноваційної раціоналізації без порушень принципів системної безпеки зі застосуванням підходів вирішення USB-проблем, інтерактивної перцепції, профайлінгу, емоційного інтелекту засобами IКТзв'язку). У структурно-логічному ланцюгу викладу за рівнями у критеріях, визначено відповідність: достатнього суспільного доступу рівноправності здобувачів освіти в соціальноглобальному виміру академічної мобільності першого критерію (володіння вокабуляром комунікативної взаємодії, професійнокатегоріального апарату для вирішення IКTзавдань сфери зв'язку 3 асертивною спроможністю антикризового управління якістю освітньої політики); другого (раціональнооптимальна сформованість комунікативної компетентності зв'язку для ІКТ-діяльності за технічними регламентами нормативно-правового регулювання); третього (семантика організації процесу профпідготовки до системної ІКТ діяльності 3 програмним забезпеченням обслуговування сфери освіти, науки й інноватики 3 практичними спроможностями комунікативного прогнозування та моделювання стану розвитку соціокультурних форм); високого ноосферноквалітологічної креативної реалізації пролонгованої зайнятості та розвитку менеджерів першого критерію (сформованість комунікативних компетентностей розвитку систем нелінійного характеру організації профпідготовки у 3ВО); другого (сформованість компетентностей у здатностях адмінуправлінського вирішення проблемно-специфічних завдань особистісного вибору форм самоосвіти, менеджменту, організації та вдосконалення згідно інноваційних методик колсантингово-дорадчих сервісів ІК-зв'язку правового та технічного регулювання управління); третього (релевантність сформованості комунікативної компетентності майбутніх менеджерів у профпідготовці, виражена у соціоекономічних, еколого-безпечних спроможностях сталості адміністративного впливу на соціокультурні форми ЗВО з реалізацією академічного потенціалу).

\section{ЛІТЕРАТУРА}

1. Армстронга М. Практика управления человеческими ресурсами. 10-е издание. перевод с английского С.К. Мордвинова. 2020. СанктПетербург. 848 с.

2. Boxall P. Twenty-First-Century Fiction : A Critical Introduction. 2013. Cambridge : Cambridge University Press. 275 p. 
3. Bakhmat N., Ridei N., Liubarets V., Ivashchenko V., Petrovska O., Averina K. Evaluation of the peculiarities of the implementation of the impulse stimulus of students in the process of educational activity. Systematic Reviews in Pharmacy. 2020. Vol 11, Issue 11. pp. 1037-1041.

4. Герберт Д., Розенштиль фон Л. Организационная психология. Человек и организация : перевод с немецкого. 2006. Харков : Изд-во “Гуманит. Центр" О.А. Шипилова. 624 с.

5. Енциклопедія державного управління : у 8 т. / Нац. акад. держ. упр. при Президентові України; наук.-ред. колегія : Ю.В. Ковбасюк (голова) та ін. 2011. Київ : НАДУ, Т. 2 : Методологія державного управління / наук.-ред. колегія : Ю.П. Сурмін (співголова), П.І. Надолішній (співголова) та ін. 692 с.

6. Мультимодусні засади післядипломної освіти для сталого розвитку: колективна монографія / за заг. редакцією Рідей Н.М., Сергієнко В.П. Видво НПУ імені М.П. Драгоманова. 2017.634 с.

7. Національний класифікатор України: класифікатор професій. ДК 003: 2010. Київ: Держспоживстандарт України. Законодавство України. URL: https://zakon.rada.gov.ua/rada/show/ va327609-10 (дата звернення : 28.11.2020).

8. Титова Н.М. Модель психолого-педагогічної підготовки педагогів професійного навчання. Освітній дискурс. Гуманітарні науки: збірник наукових праць. 2018. Київ : Вид-во “Гілея”. Вип. 7 (8). C. $31-40$.

\section{REFERENCES}

1. Armstronga, M. (2020). Praktika upravleniya chelovecheskimi resursami [Human Resource Management Practice]. the10th edition. translation from English. S.K. Mordvinova. 2020. Saint Petersburg, 848 p. [in Russian].
2. Boxall, P. (2013). Twenty-First-Century Fiction : A Critical Introduction. Cambridge : Cambridge University Press. 275 p. [in English].

3. Bakhmat, N., Ridei, N., Liubarets, V., Ivashchenko, V., Petrovska, O. \& Averina, K. (2020). Evaluation of the peculiarities of the implementation of the impulse stimulus of students in the process of educational activity. Systematic Reviews in Pharmacy. Vol 11, Issue 11.pp. pp. 1037 1041. [in English].

4. Gerbert D., Rozenshtil fon L. (2006). Organizatsionnaya psikhologiya. Chelovek i organizatsiya : perevod s nemetskogo [Organizational psychology. Person and Organization: translated from German]. Kharkov, 624 p.[in Russian].

5. Entsyklopediia derzhavnoho upravlinnia : $\mathrm{u} 8 \mathrm{t}$. [Encyclopedia of Public Administration: in 8 vols.]. Nat. acad. state maneg. under the President of Ukraine; scientific editor Board: Yu.V. Kovbasyuk (head). 2011. Kyiv, 692 p. [in Ukrainian].

6. Multymodusni zasady pisliadyplomnoi osvity dlia staloho rozvytku: kolektyvna monohrafiia (2017). [The multimodus principles of postgraduate education for sustainable development: a collective monograf]. (Ed.). Ridei, N.M. \& Sergiyenko, V.P. 634 p. [in Ukrainian].

7. Natsionalnyi klasyfikator Ukrainy: klasyfikator profesii. DK 003: 2010 [National Classifier of Ukraine: Classifier of Professions. DK 003: 2010]. Kyiv. Available at: https://zakon.rada.gov.ua/rada/show/ va327609-10 (Accessed 28 Nov.2020). [in Ukrainian].

8. Tytova, N.M. (2018). Model psykholohopedahohichnoi pidhotovky pedahohiv profesiinoho navchannia [The model of psychological and pedagogical training of teachers of vocational training]. Educational discourse. Humanities: a collection of scientific works. Kyiv. Vol. 7 (8). pp. 31-40. [in Ukrainian].

Стаття надійшла до редакції 03.11.2020

\section{G5808012058080}

"Жолоранқу я дивився на себе в дзеркало і питав: "Якби сьогодні був останній день мого життя, хотів би я займатися тим, чим я займаюся съогодні? I якщо відповідь протягом багатьохднів поспіль була “ні" - язав, що мені потрібно щось змінювати”.

Cmis Dжобс

америқансьқий підприємець і винахідник

“Культура не змінюється тому, що ми хочемо ї̈ змінити. Культура змінюється, коли організаиія трансбормується; культура відображає реалї людей, які щодня працюють разом".

Френсіс Тессельбейн американський письменник, консультант по менеджменту

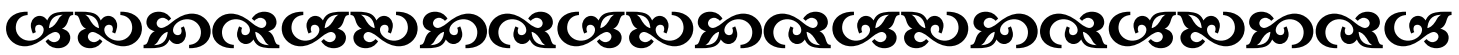

